\title{
THE LIMITING STORAGE LIFE OF PERISHABLES DURING JOINT TRANSPORTATION
}

\author{
Nurlan Kurmanov ${ }^{1}$, Baurzhan Tolysbayev ${ }^{2}$, Yermek Abilmazhinov ${ }^{3}$
}

\begin{abstract}
The article presents the research results of the optimal storage period for perishable products, which require specific thermal and temperature-humidity conditions, during joint transportation. A new classification to group perishable products that are subject to joint transportation by moisture and water activity is proposed. The calculations show that perishable goods during joint transportation need the following optimal parameters: an air temperature of the cargo space of -5 to $0{ }^{\circ} \mathrm{C}$, relative humidity of $75-95 \%$, and storage life of no more than 10 days while in transit.
\end{abstract}

UDC Classification: 656.1, DOI: http://dx.doi.org/10.12955/cbup.v3.644

Keywords: Water activity, storage modes, short-lived commodities, transporting, thermal state

\section{Introduction}

Effective transportation, especially in terms of transporting perishable goods optimally through a refrigeration transport chain, is an important component of the production activity of meat processing companies.

The problems relating to delivery of perishables in today's society should be approach rationally. Having created optimal storage conditions for maintaining food quality while minimizing the costs of refrigeration, processing, and transportation, are the main indicators of improvement and optimization of vehicles and their components for the transport of perishables (Tolysbayev \& Abilmazhinov, 2007; Bolshakov, 2006).

The maintenance technology of perishables determines the transportation technology.

The continuity of a refrigeration transport chain requires compliance with similar conditions to those set down for stationary refrigerated storage areas and other refrigerated transport. We consider that, currently, the meat processing enterprises of Kazakhstan aim to expand the market realization of products. Also, according to the Statistics Agency of the Republic of Kazakhstan, the volume of transported perishables is increasing at about $6 \%$ of the total turnover. Shipment of these products is mainly by road and rail-refrigeration (Law of the Republic of Kazakhstan from "On Automobile Transport", 2003; Rules of goods' transportation by road, 2011; Terms of railway transportation, 2011). The long-haul transportation outside the country is well planned, particularly in countries of Central and Southern Asia. In these areas, there has been widespread introduction of advanced technologies for transportation of perishables in recent years. One such technology is the use of 'container' shipping. The efficiencies in using container shipping largely depend on similar conditions to those that affect joint transportation of foodstuffs and agricultural products, given they are subject to the same transportation requirements.

\section{Materials and methods}

In current practice, depending on the requirements, all perishables during joint transportation are grouped into three groups (Ryall \& Pentzer, 1982; Gill, 1996; Angelov, 2011).

The inclusion of indicators, such as humidity and water activity of the product, which affect joint transportation, were not considered in the grouping of perishables. Below are the characteristics relating

\footnotetext{
${ }^{1}$ Nurlan Kurmanov, PhD, Kazakh University of Economics, Finance and International Trade, Republic of Kazakhstan, n.a.kurman@mail.ru

${ }^{2}$ Baurzhan Tolysbayev, PhD, L.N. Gumilyov Eurasian National University, Kazakhstan

${ }^{3}$ Yermek Abilmazhinov, PhD, Kazakh Humanitarian Juridical Innovative University, Kazakhstan
} 
to the existing three perishable groups that are relevant for joint transportation. Based on the foregoing, we consider the grading of these indicators for the groups of perishables, as shown in Table 1.

Table 1: Group I - Frozen products. Storage modes: air temperature in the cargo space no higher than $-12^{\circ} \mathrm{C}$ at a relative humidity of $70-80 \%$, with moderate circulation at a rate no higher than 0.2 $-0.3 \mathrm{~m} \mathrm{~s}^{-1}$. Storage life in transit is not more than 30 days.

\begin{tabular}{|c|l|c|c|}
\hline$\#$ & \multicolumn{1}{|c|}{ Product } & $\begin{array}{c}\text { Humidity } \\
\boldsymbol{W}, \boldsymbol{\%}\end{array}$ & $\begin{array}{c}\text { Water activity, } \\
\boldsymbol{a}_{\boldsymbol{w}}\end{array}$ \\
\hline $\mathbf{1}$ & Frozen beef and mutton & $70-75$ & $0.98-0.992$ \\
\hline $\mathbf{2}$ & Frozen pork & $70-75$ & $0.978-0.986$ \\
\hline $\mathbf{3}$ & $\begin{array}{l}\text { Frozen offal (tongue, udder, heart, } \\
\text { kidneys, and brain) }\end{array}$ & $80-85$ & $0.98-0.9891$ \\
\hline $\mathbf{4}$ & Meat and offal; frozen in blocks & $70-85$ & $0.98-0.9891$ \\
\hline $\mathbf{5}$ & Frozen poultry & $65-75$ & 0.979 \\
\hline $\mathbf{6}$ & Bacon fat & 70 & 0.977 \\
\hline $\mathbf{7}$ & Butter & 75 & 0.971 \\
\hline $\mathbf{8}$ & Margarine & 75 & 0.97 \\
\hline
\end{tabular}

Source: Authors

Table 2: Group II - Frozen and chilled products. Storage modes: air temperature in the cargo space of between $-5^{\circ} \mathrm{C}$ and $0^{\circ} \mathrm{C}$. Storage life in transit is not more than 15 days.

\begin{tabular}{|c|c|c|c|}
\hline$\#$ & Product & $\begin{array}{c}\text { Humidity } \\
W(\%)\end{array}$ & $\begin{array}{c}\text { Water activity } \\
a_{w}\end{array}$ \\
\hline $\mathbf{1}$ & Chilled beef and mutton & $65-75$ & $0.98-0.992$ \\
\hline 2 & Chilled pork & $65-75$ & $0.978-0.986$ \\
\hline 3 & & $85-95$ & $0.98-0.9891$ \\
\hline 4 & $\begin{array}{l}\text { Frozen culinary products from minced } \\
\text { meat (goulash, burgers, steaks, meatballs, } \\
\text { and schnitzel) }\end{array}$ & $65-85$ & $0.98-0.9891$ \\
\hline 5 & Sausages (wieners and sausages) & 35 & 0.9715 \\
\hline 6 & $\begin{array}{l}\text { Combined meat and cereal products } \\
\text { (meat dumplings, etc.) }\end{array}$ & - & - \\
\hline 7 & Butter & 75 & 0.971 \\
\hline 8 & Margarine & 75 & 0.97 \\
\hline
\end{tabular}

Source: Authors

Table 3: Group III - Chilled food. Storage modes: air temperature in the cargo storage area within the range $0-6^{\circ} \mathrm{C}$ at a relative humidity of $70-85 \%$. Storage life in transit not more than 10 days.

\begin{tabular}{|c|l|c|c|}
\hline$\#$ & \multicolumn{1}{|c|}{ Product } & $\begin{array}{c}\text { Humidity } \\
\boldsymbol{W}(\%)\end{array}$ & $\begin{array}{c}\text { Water activity } \\
\boldsymbol{a}_{w}\end{array}$ \\
\hline $\mathbf{1}$ & $\begin{array}{l}\text { Pates of meat, liver, and poultry } \\
\text { produced by industry }\end{array}$ & 21 & 0.9891 \\
\hline
\end{tabular}




\begin{tabular}{|c|l|c|c|}
\hline $\mathbf{2}$ & Sausages & 24 & 0.78 \\
\hline $\mathbf{3}$ & $\begin{array}{l}\text { Culinary products from minced meat, } \\
\text { fried (goulash, burgers, steaks, meatballs, } \\
\text { and schnitzel) }\end{array}$ & 22 & 0.79 \\
\hline
\end{tabular}

Source: Authors

Finding ways to reduce the loss of perishable goods in transit is inextricably linked to an objective assessment of the quality characteristics. Widespread species loss relating to the quality of the product is linked to shrinkage. It is now scientifically proven that a product contains moisture in three types: strongly bound, free, and loosely coupled. The change in state of moisture in the product depends on many parameters. In particular, the temperature and humidity of air, and change in the water activity of the product itself, greatly affect shrinkage of the product.

The water activity in this case is defined as the ratio of the water-vapor pressure of the product to that of the pure solvent used in establishing thermodynamic equilibrium. Water activity was measured by a manometric method in a suitable machine (Kamerbayev, 2001). The installation of this machine included a differential gauge, a flask with the product and distilled water, a vacuum pump, a trap, a thermocouple, and a potentiometer for testing the temperature of the product.

Water activity is calculated by the formula:

$$
a_{w}=\frac{P_{n p}}{P_{o}}=\frac{P_{o}-\Delta P}{P_{o}}
$$

where $P_{n p}-$ is the partial vapor pressure of meat products; and

$P_{o}-$ is a steam partial pressure of distilled water.

Shrinkage of the product was determined by way of an experimental stand that remotely measured the time step ( $h=1$ hour), without breaking the heat and humidity modes (Gill \& Phillips, 1993). Moisture evaporation from the model broke the equilibrium state of the sample weights, and forced equal effect on the mass of removed moisture, which was transferred to a steel elastic beam, where four strain gauges (AKA-10.200V, TU25.06, 1382-78) were attached, with each connected to a bridge circuit of $200 \mathrm{ohms}$. The signal from the strain gauges entered the strain amplifier, "TOPAZ-4", and then transferred onto the C-75 oscilloscope.

Separate experiments were carried out for samples of meat, which weighed $5.02 \mathrm{~kg}$ for beef, $5.135 \mathrm{~kg}$ for mutton, and $5.01 \mathrm{~kg}$ for preserved meat. Temperature-humidity conditions were set with air temperature $\pm 30^{\circ} \mathrm{C}$ and absolute humidity $60-95 \%$.

\section{Results and discussion}

As it can be seen, the storage life of perishables depends on air temperature. However, the storage life must ensure the preservation of the quality of products. Product quality is determined mainly by the acidity $(p H)$, and water activity $\left(a_{w}\right)$ of the product. The technique of determining the storage life of perishables based on the $\mathrm{pH}, a_{w}$ and storage temperature of the product is proposed (James, James, \& Evans, 2006).

The peculiarity of this technique is that you can determine the storage life of a perishable product at any stage of storage and transportation to the next, based on

$$
\tau_{x p}=1,15 \cdot A \cdot p_{1} \cdot \ln \left(B \cdot a_{w}\right)+C \cdot p_{2} \int_{a}^{b} \ln (p H) d(p H)
$$


In our case, for the following products: meat chilled, cooked sausages and minced meat, the coefficients and constants were empirically determined.

\begin{tabular}{|c|c|}
\hline \multicolumn{2}{|l|}{ Table 4: Empirical coefficients } \\
\hline $\begin{array}{l}\text { The storage of products at the stages of storage } \\
\text { in the enterprise and transportation: }[t]=-4{ }^{\circ} \mathrm{C} \\
-0\end{array}$ & $\begin{array}{l}\text { The storage of products at the stage of } \\
\text { realization }[t]=0-8{ }^{\circ} \mathrm{C}\end{array}$ \\
\hline$A=5.5(1-\varphi) e^{-\varphi(t-5)}$ & $A=5.5(1-\varphi) e^{-\varphi \sqrt{(5-t / 1.6)}}$ \\
\hline$B=\frac{0.235}{1-\varphi} e^{t^{2} \varphi}$ & $B=\frac{0.235}{(1-\varphi)} e^{\varphi} \sqrt{([t]-t)^{3}}$ \\
\hline$C=80 \cdot \varphi^{2}$ & $C=0.5 \cdot \varphi^{2}$ \\
\hline \multicolumn{2}{|c|}{} \\
\hline
\end{tabular}

A graph of the perishable products' deadlines in relation to different modes of temperature and humidity is presented in Figure 1.

Figure 1: Deadlines for storage of meat and meat products, in relation to different technological regimes

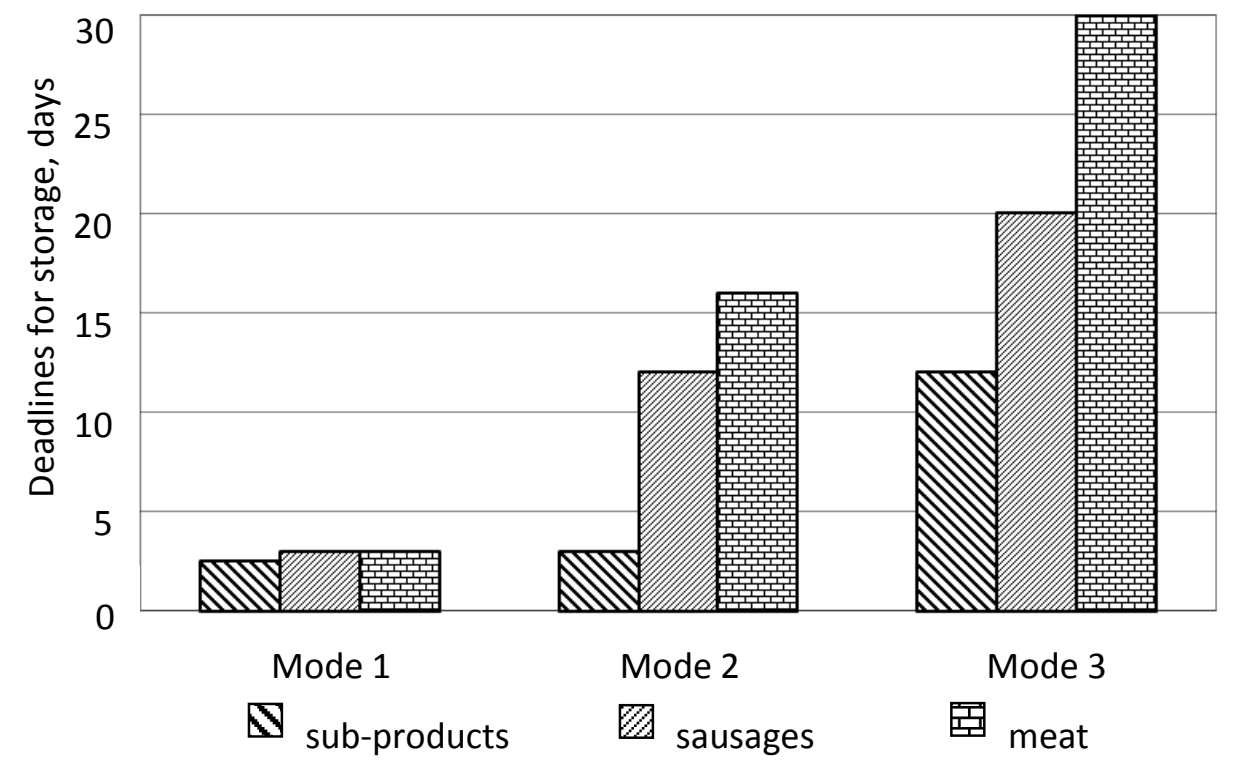

Mode 1 - air temperature not higher than $6^{\circ} \mathrm{C}$, relative humidity $80-95 \%$;

Mode 2 - air temperature not higher than $0^{\circ} \mathrm{C}$, relative humidity $75-95 \%$;

Mode 3 - air temperature of $-5{ }^{\circ} \mathrm{C}$, relative humidity $75-80 \%$.

Source: Authors

Figure 2 shows the weight change of perishable products according to different modes of storage. 


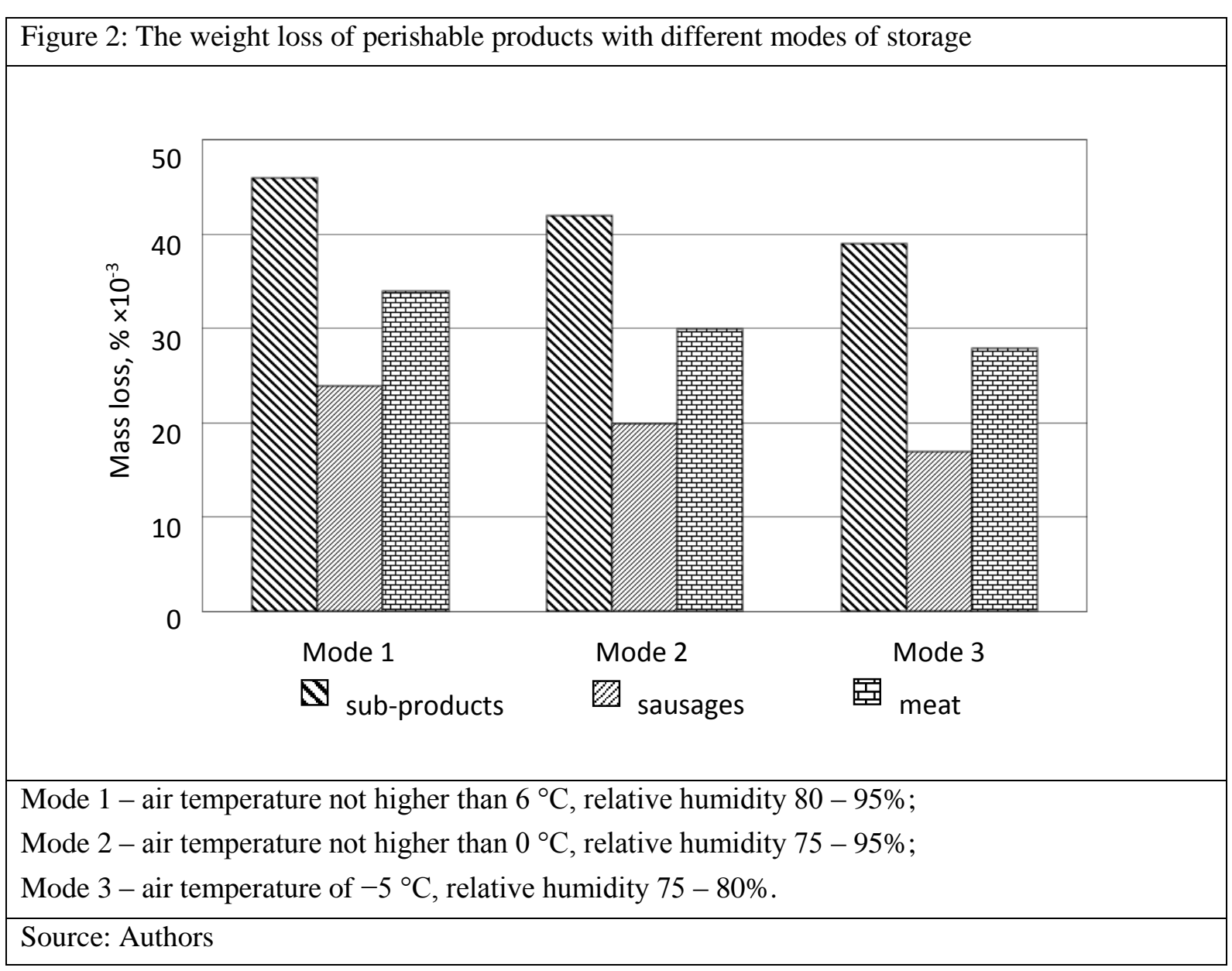

As we can see from Figure 1, the deadlines for storage at air temperatures between $0^{\circ} \mathrm{C}$ and $-5^{\circ} \mathrm{C}$ are higher than those for storage at $0-6{ }^{\circ} \mathrm{C}$. Figure 2 shows that compared to results for air temperatures not higher than $6^{\circ} \mathrm{C}$, weight loss is apparent for temperatures less than $0^{\circ} \mathrm{C}$ and $5{ }^{\circ} \mathrm{C}$, respectively.

Tables 5, 6, and 7 show the limits of storage for perishable goods, respectively, for the three groups in the proposed grouping for joint transportation.

\begin{tabular}{|l|c|c|}
\hline \multicolumn{1}{|c|}{ Product } & $\begin{array}{c}\text { At the stage of storage in } \\
\text { the enterprise and } \\
\text { transportation: } \\
{[t]=-\mathbf{4}-\mathbf{0}^{\circ} \mathbf{C}}\end{array}$ & $\begin{array}{c}\text { At the stage of the } \\
\text { realization } \\
{[t]=\mathbf{0}-\mathbf{8}^{\circ} \mathbf{C}}\end{array}$ \\
\hline Frozen beef and mutton & 30 & 3 \\
\hline Frozen pork & 30 & no more than 2 \\
\hline $\begin{array}{l}\text { Frozen offal (tongue, udder, heart, } \\
\text { kidneys, and brain) }\end{array}$ & 20 & 1 \\
\hline Meat and offal; frozen in blocks & 30 & 2 \\
\hline Frozen poultry & 20 & 1 \\
\hline Bacon fat & 12 & 1 \\
\hline Butter & 20 & \\
\hline Margarine & 20 & \\
\hline Source: Authors & & \\
\hline
\end{tabular}




\begin{tabular}{|l|c|c|}
\hline \multicolumn{1}{|c|}{ Table 6: Shelf life of perishable goods in the second group (days) } \\
\hline \multicolumn{1}{|c|}{$\begin{array}{c}\text { At the stage of storage in } \\
\text { the enterprise and } \\
\text { transportation: }[t]= \\
-\mathbf{4}-\mathbf{0}{ }^{\circ} \mathbf{C}\end{array}$} & $\begin{array}{c}\text { At the stage of } \\
\text { realization } \\
{[t]=\mathbf{0}-\mathbf{8}^{\circ} \mathbf{C}}\end{array}$ \\
\hline Chilled beef and mutton & 5 & 3 \\
\hline Chilled pork & 5 & 3 \\
\hline Chilled carcasses of poultry and rabbits & 5 & 3 \\
\hline $\begin{array}{l}\text { Frozen culinary products from minced } \\
\text { meat (goulash, burgers, steaks, meatballs, } \\
\text { and schnitzel) }\end{array}$ & 12 & 5 \\
\hline Sausages (wieners and sausages) & 10 & 3 \\
\hline $\begin{array}{l}\text { Combined meat and cereal products (meat } \\
\text { dumplings, etc.) }\end{array}$ & 5 & 1 \\
\hline Butter & 5 & 2 \\
\hline Margarine & 5 & 2 \\
\hline
\end{tabular}

Source: Authors

Table 7: Shelf life of perishable goods in the third group (days)

\begin{tabular}{|l|c|c|}
\hline \multicolumn{1}{|c|}{ Product } & $\begin{array}{c}\text { At the stage of storage in } \\
\text { the enterprise and } \\
\text { transportation: }[t]= \\
-\mathbf{4}-\mathbf{0}{ }^{\circ} \mathbf{C}\end{array}$ & $\begin{array}{c}\text { At the stage of } \\
\text { realization } \\
{[t]=\mathbf{0}-\mathbf{8}^{\circ} \mathbf{C}}\end{array}$ \\
\hline $\begin{array}{l}\text { Pates of meat, liver, and poultry produced } \\
\text { by industry }\end{array}$ & 15 & 7 \\
\hline Sausages & 15 & 3 \\
\hline $\begin{array}{l}\text { Culinary products from minced meat, } \\
\text { fried (goulash, burgers, steaks, meatballs, } \\
\text { and schnitzel) }\end{array}$ & 5 & 1 \\
\hline Source: Authors & & \\
\hline
\end{tabular}

\section{Conclusion}

The calculations show that perishable goods during joint transportation need the following optimal parameters: an air temperature of the cargo space of -5 to $0{ }^{\circ} \mathrm{C}$; relative humidity of $75-95 \%$; and storage life, while in transit, of not more than 10 days.

\section{References}

Angelov, M. (2001). Development of agro technical service. AlPari, 3. 25-29.

Bolshakov, S.A. (2006, January). Terms, conditions and features of the transport of various food products. Internet paper Refrigeration.ru, 1(13).

Gill, C. O., \& Phillips, D. M. (1993). The efficiency of storage during distant continental transportation of beef sides and quarters. Food research international, 26(4), 239-245.

Gill, C. O. (1996). Extending the storage life of raw chilled meats. Meat science, 43, 99-109.James, S. J., James, C., and Evans, J. A. (2006). Modelling of food transportation systems-a review. International Journal of Refrigeration, 29(6), 947-957. 
CBU INTERNATIONAL CONFERENCE ON INNOVATION, TECHNOLOGY TRANSFER AND EDUCATION

Kamerbayev, A. Y. (2001). The role of water in food products and its function. Almaty: Mariya LLC.

Law of the Republic of Kazakhstan "On Automobile Transport”. (2003). \#476-II. Retrieved from http://www.zakon.kz

Rules of goods' transportation by road. (2011). Approved by the Government of the Republic of Kazakhstan from 18.07.2011 \# 826. Retrieved from http://www.zakon.kz

Ryall, A. L., \& Pentzer, W. T. (1982). Handling, transportation and storage of fruits and vegetables. Volume 2. Fruits and tree nuts. Westport CT: AVI Publishing Co. Inc.

Terms of railway transportation. (2011). Approved by the Government of the Republic of Kazakhstan from 21.06.2011 \# 682. Retrieved from http://www.zakon.kz

Tolysbayev, B. S., \& Abilmazhinov, E. T. (2007). Refrigeration and transport chain for meat products: Theory and Practice. Monograph. State University named after Shakarim Semey city. 